\title{
A büntetés-végrehajtási szervezet reintegrációs tevékenységeinek új rendszere
}

A büntetés-végrehajtási intézetekben lévó fogvatartottakat büntetésük ideje alatt ingerszegény környezet veszi körül, amelyben a külvilágtól eltéró rendszabályok uralkodnak. Napjainkban

fokozatosan erósödik az igény arra, hogy ezekben az intézményekben a fogvatartottak reintegrációjának elérése érdekében számos olyan tevékenységet is ellássanak, amelyek túlnónek a klasszikus igazságszolgáltatás keretein.

A büntetés-végrehajtási tevékenységben meghatározó szerephez jutnak a közremüködö társadalmi, egyházi, karitatív és civil szervezetek. A börtönlelkészi látogatások, foglalkozások, valamint a civil szervezetek közösségi, szociális tevékenysége hozzájárul ahhoz, hogy a fogvatartottak minél kevesebb lelki sérüléssel tudjanak. visszaintegrálódni a társadalomba.

A büntetés-végrehajtási szervezet a fogvatartottak társadalomba visszailleszkedésének, reintegrációjának elérése érdekében számos olyan tevékenységet ellát, amelyek túlmutatnak a klasszikus igazságszolgáltatás keretein, ezen tevékenységeket kívánom bemutatni ebben a tanulmányban. Ennek hátterében a 2013. évi CCXL. törvény azon rendelkezése áll, amely elöírja, hogy a szabadságvesztés végrehajtása során biztosítani kell, hogy az elítélt felkészüljön a szabadulása utáni, a társadalom elvárásának megfelelö önálló életre (2013. évi CCXL. törvény 83. § [7]). E feladat végrehajtása érdekében az elítéltek társadalmi beilleszkedését elősegítő reintegrációs tevékenységet a végrehajtásért felelős szerv az elítéltek munkáltatása, terápiás foglalkoztatása, továbbá általános iskolai, illetve középfokú iskolai oktatása, felsőfokú tanulmányok végzése, szakképzése, szakmai gyakorlat megszerzése, valamint egyéb reintegrációs programok által biztosítja (2013. évi CCXL. törvény 83. § [3]).

A felsorolt célkitűzések elérése érdekében a büntetés-végrehajtásnak „le kell képeznie" a külső valóságot, úgy kell szervezni a végrehajtást, hogy a feladatok ellátásával közelebb jusson a rendszer a deklarált célhoz, a fogvatartottakkal való méltányos és humánus bánásmódhoz, ezen keresztül a visszailleszkedés segítéséhez (Garami, 1997). Az utóbbi évtizedekben fokozatosan erősödött az igény arra, hogy a büntetés-végrehajtási intézetek olyan programokat dolgozzanak ki, amelyek elősegítik a testi és szellemi képességek megtartását, fejlesztését, valamint amelyek által a fogvatartott lehetőséget kap egy „társadalom-konformabb” élet megvalósítására (Czenczer, 2008). A börtönben lévő fogvatartottakat büntetésük ideje alatt ugyanis egy mesterséges világ veszi körül, amelyben a külvilágtól eltérő rendszabályok uralkodnak. Ebből adódóan gondolatkörük és problémáik specifikusak, szük körben mozognak, legfontosabb feladatuk az idő múlásának várása. Burik szerint a társadalomból való tartós kirekesztettség által gyengül a fogvatartottak önértékelése, 
önbecsülése, önálló életvitelre való képessége, valamint kommunikatív képessége. Ezen hiányosságok elsajátításához nyújt segítséget a tanárok, a civil szervezetek, az egyházak, segítők jelenléte (Burik, 2011).

\section{A büntetés-végrehajtási intézetek által alkalmazott tevékenységek}

Az intézetek oktatási, egyházi és civil szervezetek közremüködésével alkalmazott tevékenységei szorosan kapcsolódnak a mindennapi tevékenységhez, céljuk a feszültségoldás, a személyiségfejlesztés és az önmegismerés, emellett csökkentik a börtön karcerizáló, izoláló hatását is. Czenczer (2008) szerint hatásukra alacsonyabb szintet ér el az intézeten belüli feszültség, valamint a prizonizációs hatás, és a külvilággal való közvetlenebb, aktívabb kapcsolat elősegíti a szabadulás utáni eredményesebb beilleszkedést.

A felsorolt pozitív célok elérése érdekében nagyon fontos az együttmüködés, ami az egyes büntetés-végrehajtási intézetek és környezetük között jön létre. A korábban tapasztalt, kölcsönös elzárkózás az elmúlt húsz évben megszünt. Napjainkban az a felfogás uralkodó, hogy az elítéltek művelődése, képzése, kezelése, utógondozása előkészítése érdekében az intézet környezetében működő oktatási, szakképzési, közművelődési, ismeretterjesztő intézményekkel, egészségügyi és rehabilitációs szolgálatokkal, munkaügyi és családsegítő központokkal szoros kapcsolatot kell kialakítani (Lörincz és Nagy, 1997). A rendszerváltás idejére a magyar büntetés-végrehajtás szakmai szervezetté vált. Kiépültek az elítéltekkel foglalkozó szakmai csoportok, például a nevelési szolgálat, belső felügyelet, újjáéledtek azok az egyházi, karitatív és társadalmi szervezetek, amelyek az intézetek falain belül és azon kívül segítséget nyújtottak a büntetés-végrehajtás céljainak megvalósításában, így a közművelődés, lelki és szellemi gondozás, a szabadulás utáni beilleszkedés nehézségeinek megoldásában (Ruzsonyi, 1999). Az 1990-es évektől jellemző a büntetés-végrehajtási intézetek és környezetük közötti interakció szélesedése. Ez a nyitottság alkalmas lehet arra, hogy „csökkentse az intézet környezetében az elítéltekkel szemben táplált ellenérzéseket, és megkímélje a büntetés-végrehajtást a túlzó, illuzórikus elvárásoktól" (Lörincz és Nagy, 1997).

A törvényalkotó olyan rendszer létrehozását tartotta kívánatosnak, amelyben a hivatalos és társadalmi szervezetek kiegészítik egymás tevékenységét a társadalom és a fogvatartottak érdekében. Ebből kifolyólag jogszabály írja elő az együttmüködési, tájékoztatási és segítségnyújtási kötelezettség részletes szabályainak meghatározása során, hogy a büntetés-végrehajtási szervezet ,együttmüködik a fogvatartás körülményeinek a figyelemmel kísérésére, a szabadulás után a társadalomba való beilleszkedés elősegítésére, a karitatív tevékenység végzésére, továbbá az egyéb büntetés-végrehajtási feladatok segítésére alakult börtönmissziókkal és társadalmi szervezetekkel, az ilyen tevékenységet ellátó egyházakkal, alapítványokkal és személyekkel” (1995. évi CVII. törvény 13. §).

Az együttmüködés három szereplöje, a börtön, a fogvatartott és a társadalmi szervezet más érdekek, szabályok szerint müködik, ezért fontos tevékenységeik összehangolása. A börtön a feltételeket biztosítja, a szervezet az alapszabályában lefektetett céljainak igyekszik megfelelni, a fogvatartott pedig saját döntése alapján igénybe veszi a lehetőségeket. A tevékenységek biztosítása tekintetében számos különbség van a büntetés-végrehajtási szervezet és a civil szervezetek között. A civil szervezetek saját alapszabályukban megfogalmazott célok érdekében tevékenykednek, ezek közül csak egyik a fogvatartottakkal való foglalkozás, ha viszont csak fogvatartottakkal kívánnak foglalkozni, akkor meghatározott a tevékenységi kör. Ehhez képest a büntetés-végrehajtás feladatrendszerét jogszabályok írják elő, és nem részfeladatok elvégzésére korlátozódik. A büntetés-végrehajtásnak minden fogvatartottal kapcsolatban elöírt feladatai vannak, nem élhet a személyválogatás módszerével. A szervezetek alapszabálya általában azt a 
kitételt tartalmazza, hogy a fogvatartottakkal kíván foglalkozni, és nem a börtönt akarja segíteni, még ha ez áttételesen a büntetés-végrehajtási munkát is elönyösen befolyásolja (Garami, 1997).

A szervezetek a fogvatartottak vallási igényein túl kulturális, tanulási szükségleteket is kielégítenek, emellett karitatív tevékenységet folytatnak, nem is beszélve az egyes szervezetek emberi jogvédő aktivitásáról, ahogyan ezt tanulmányomban részletesen bemutatom. A kognitív szociális kompetencia fejlesztésére irányuló folyamat hozzájárul a szabadságvesztés büntetésüket töltő személyek reszocializációs esélyeihez (Ruzsonyi, 2006). Bizonyos tevékenységek a fogvatartottak reintegrációjához feltétlenül fontosak, elősegítik a megtanult ismeretek munkaerőpiaci érvényesítését, így a büntetés-végrehajtási intézetekben folyó oktatás-képzés keretében kiemelten kell ezen területek fejlesztésével is foglalkozni. Nem hagyható figyelmen kívül a fogvatartottak müvelődésének, vallásgyakorlásának, munkával történő foglalkoztatásának, egészségügyi és szociálpolitikai ellátásának feladata, tanulmányomban részletesen kitérek ezen területek vizsgálatára is (Lörincz és Nagy, 1997). A szervezet az oktatáson kívül speciális nevelési programokat is biztosíthat a fogvatartottak számára, például a kulcskompetenciák fejlesztése érdekében, vagy agresszió- és konfliktuskezelö, álláskereső, kommunikációs, problémamegoldó, életvezetést segítő, drogprevenciós, magatartás-szabályozó, önismereti tréningek formájában. Hasznos továbbá a szabadulás utáni reintegráció érdekében a pártfogói hálózattal történő együttmüködés, valamint hajléktalan szabadulók esetében a szabadulók kérelmükre történő segélyezése, kapcsolattartás lakhatást biztosító szervezetekkel (Novák, 2004). A büntetés-végrehajtásban müködő közösségi foglalkozások közé soroljuk Czenczer (2008) szerint mindazokat a tevékenységeket, amelyek a klasszikusan „,kötelező”, intézeten belüli tevékenységek köréből (ilyen az oktatás, a szakképzés és a munka) kimaradtak. Ezeknek a foglalkozásoknak is hasonlóan nagy hatásuk van az elítéltek fejlődésére, és a jogszabályok, nemzetközi elvárások, alapelvek egyaránt megkövetelik ezek teljesítését, írásomban ezen területek vizsgálata a célom. A következő fejezetben a közösségi foglalkozások egy szeletével, az oktatás, képzés témakörével foglalkozom, különös hangsúlyt fektetve a fogvatartottak tanulását megnehezítő külső és belső körülmények bemutatására.

\section{Oktatás, képzés a büntetés-végrehajtás rendszerében}

Számos tanulmányban olvashatjuk, hogy milyen összetett problémákkal szembesülnek a fogvatartottak tanulásuk során. Sokuknak ugyanis semmilyen oktatási tapasztalatuk nincs, iskoláztatási hátrányuk, funkcionális analfabetizmusuk kezelése nagymértékben megnehezíti az oktatási tevékenységet (Eggleston, 1991; Gemignani, 1994; Stephens, 1992). A tanulási nehézségeket okozó körülmények közé a kutatók az intellektusbeli deficitek, részképesség-zavarok meglétét, így a memória, általános műveltségbeli háttér hiányait, szövegértési, olvasási, logikai, motoros hiányosságokat, zavarokat sorolják. A börtöntársadalomból kikerülő diákok között jóval nagyobb arányban vannak jelen antiszociális magatartású, illetve disszociális személyiségzavarral rendelkező személyek, nehezebben megy számukra a beilleszkedés, a kommunikáció, a problémamegoldás (Gemignani, 1994; Paul, 1991).

Több kutatás bizonyította, hogy a fogvatartottak jelentős részének negatív érzései vannak az iskolával kapcsolatban, rengeteg kudarccal szembesültek életük során, és ez problémaként jelentkezik a börtönben történő tanuláskor is (Hurry és mtsai, 2005; Paul, 1991; Vacca, 2004).

Mivel a fogvatartottak gyerek- és serdülőkorukban nagyobb arányban maradnak ki az iskolából, ahol nem elég jól vagy egyáltalán nem teljesítenek, a műveltségbeli hiányosságok és a tudásdeficit egészen komoly is lehet. Az iskolai szocializáció hiánya ugyanakkor 
további hatásokat is gyakorol a fogvatartottak személyiségének fejlődésére. A legtöbb fogvatartott nemcsak a tanulási folyamatokból esett ki, de az iskolai szocializáció oly fontos részét képező közösségi tevékenységeken sem vett részt (Paul, 1991).

Mindezen nehézségek ellenére sok elönnyel jár a börtönben folytatott tanulás. Gerber és Fritsch (1993) munkájában felhívta a figyelmet arra, hogy az oktatásban részt vevő elítéltek esetében kevesebb fegyelmezési probléma volt a börtönben, sokkal kisebb arányban váltak visszaesővé, követtek el újabb büncselekményt szabadulásuk után. A börtönoktatás kedvező hatással van a fogvatartottak szabadulás utáni életvitelére, ritkábban sértik meg a feltételes szabadulás előírásait, gyorsabban találnak munkahelyet.

Hazánkban a fentebb bemutatott összetett probléma orvoslására törvény írja elö, hogy „,az elítéltet - büntetésének tartamához képest - betanított-munkás képzésben, szakmunkásképzésben, vagy a bv. intézet lehetősége szerint, a büntetés-végrehajtási szempontokra is figyelemmel, szakképzésben kell részesíteni, valamint - ha a bv. intézet parancsnoka engedélyezi - támogatható, hogy a felsőfokú tanulmányokat megkezdje vagy folytassa" (2013. évi CCXL. törvény 164. § [1]). A büntetés-végrehajtási intézetek az oktatási intézményekkel szerződéses kapcsolatban állnak. Szerződött félként lehetséges egyházi és alapítványi iskolák müködtetése is. Az oktatási intézménynek a fogvatartásra való utalás nélkül kell a bizonyítványt kiállítania (16/2014. [XII. 19.] IM rendelet 117. $\S[4])$. Fontos a szoros együttmüködés kialakítása az adott büntetés-végrehajtási intézet vezetése és az oktatási intézmény között, hiszen az iskola tevékenységét össze kell hangolni a börtön szigorúan szabályozott életével.

A büntetés-végrehajtási intézetben ugyanakkor gyakran problémát okoz az a bizonytalan környezet, amelyben a fogvatartottak élnek. Az oktatásban, képzésben való részvételi arány csökkenéséhez vezethet például, ha egy elítéltet másik intézetbe szállítanak, vagy idő elött szabadul (Brosens és mtsai, 2015; Callan és Gardner, 2005). Számos esetben problémaként jelenik meg a képzés tekintetében a rövid ítéletet töltő fogvatartottak esete. A büntetés-végrehajtási intézetben rövid ideig fogvatartott személyek esetén nehéz öket igazán hatékonyan bevonni a tanulásba, érdekeltté tenni az oktatás vonatkozásában, sokszor alulmotiváltak, esetükben nagyobb az esélye a visszaesésnek, a bünöző életmódhoz való visszatérésnek szabadulásuk után (Brosens és mtsai, 2015; O'Keeffe és mtsai, 2007).

Ezen nehézségek kezelésében nagyon fontos szerepe van a börtönoktatásnak, a börtöntanároknak. Ha a pedagógusok teljes emberként kezelik a fogvatartottakat, akik képesek fejlődni, eredményeket elérni, törődéssel ${ }^{1}$ fordulnak feléjük, akkor tanulási tevékenységük is sokkal hatékonyabb lesz ezáltal (Vacca, 2004; Wright, 2004). A törődés, a fogvatartottak felé fordulás mellett nem elhanyagolható körülmény az a környezet, ahol az elítéltek tanulni tudnak.

$\mathrm{Az}$ iskola tere a börtönben az intézet sajátosságaitól függ. Büntetés-végrehajtási intézetben általában müködik iskola- vagy kultúrkörlet, ahol a fogvatartottak szabadabban mozoghatnak, emellett közösségi helységek, terápiás szobák is szolgálhatnak a tanulás helyszínéül. A kis létszám lehetővé teszi a személyességet, az egymás mellett helyet foglalást a segítő tanár és a fogvatartott között, azaz a tér felosztása nem hierarchizált. A hatalmi-hierarchikus elrendezés a tanulás-segítés folyamatában felbomlik, és személyes, emberi kapcsolatok jönnek létre. Az adó-befogadó szerep felcserélődhet és aktív, folytonos kommunikáció jön létre, amelyben mindkét fél szimmetrikus viszonyban érezheti magát, ami elengedhetetlen, mert a tanulásban nagyfokú önállóságra, egyéni kezdeményezésekre van szükség (Csáki és Mészáros, 2003). Nem azonos azonban az alap- és középfokú oktatás büntetés-végrehajtási rendszer általi támogatottsága.

Az alapfokú iskolai végzettség megszerzését különösen ösztönözni és támogatni kell, az általános iskolai oktatásban részt vevők tanszereit, tankönyveit és az oktatás egyéb költségeit a büntetés-végrehajtási szervezet biztosítja (16/2014. [XII. 19.] IM rendelet 117. § [5]). A 2013. évi CCXL. törvény 164. § (2) és (4) ugyanis az elítélt végrehajtás 
tényéből eredő jogaként rendelkezik az önképzés, valamint az általános iskolai képzésben való részvétel jogáról. A nemzetközi normákkal összecsengően a jelenlegi szabályozás már nem kötelezettségként, hanem az életkortól függetlenül az elítélt jogaként határozza meg az általános iskolai tanulmányok folytatását (Juhász, 2002). Az általános iskolai tanulmányok 40 éves korig kötelező folytatásának eltörlését követően 1993-tól érezhetően csökkent az azt igénybe venni kívánó fogvatartottak száma. Ennek ellensúlyozására az 1995. évi törvénymódosítás megteremtette annak lehetőségét, hogy abban az esetben, ha az elítélt munkavégzés helyett tanulmányokat folytat, ennek idejére anyagi támogatásban részesüljön. Mindez nagyban előmozdítja az eredményességet, azonban olykor visszaélések is történnek ezzel összefüggésben.

A fogvatartottak intézeten belüli oktatásának fontosságát két további részletszabály is kiemeli, így biztosítva a tanulás lehetőségét speciális, ritkán előforduló esetekben. Az egyik ilyen szabály arra az esetre vonatkozik, amikor a jelenlegi intézmény a tanulás feltételeit nem tudja a fogvatartott részére biztosítani. Ilyenkor lehetöség van arra, hogy az elítéltet kérelmére másik végrehajtási intézetbe szállítsák, akkor is, ha ez a rendszer számára egyértelmüen pluszköltségekkel jár (2013. évi CCXL. törvény 164. § [2]). Számos esetben problémát okoz, hogy az - elsősorban az alapfokú oktatásban részt vevő - elítélt tudásszintje nem felel meg a bizonyítványában megjelölt szintnek. Ezen helyzet orvoslására vezették be azt a másik szabályt, hogy amennyiben az alapfokú oktatásban részt vevő elítélt tudásszintje a bizonyítványában feltüntetettekhez képest nagyfokú lemaradást mutat, az elítélt részére a felzárkóztatást biztosítani kell (16/2014. [XII. 19.] IM rendelet 117 . $\S[6]$ ). Ennek a két speciális esetnek a fogvatartottak tanulását elösegítő módon történő szabályozása is azt mutatja, hogy a büntetés-végrehajtási rendszer müködtetésében alapvető elvként jelenik meg az, hogy minél több elítélt részesülhessen oktatásban szabadságvesztés büntetésének letöltése során, akár akkor is, ha ennek biztosítása egyértelmüen plusz ráfordításként jelenik meg a rendszerben.

Az alapfokú oktatáshoz képest már más elbírálás alá esik a középfokú oktatásban való részvétel, valamint a felsőfokú tanulmányok folytatása. A jogalkotó a felsőoktatási rendszerben való tanulást már nem az elítéltet általánosan megillető jogként rögzíti, annak érvényesülését csak indokolt esetekre szorítja, ezzel is kifejezve a tanuláshoz való jog korlátozott voltát. Ez a megkülönböztetés véleményem szerint azt jeleníti meg, hogy a közép- és felsőfokú végzettség megszerzése már nem elsődleges cél a büntetés-végrehajtás sajátos viszonyai között. Ez a körülmény minden bizonnyal összhangban áll a hazai büntetés-végrehajtási intézetek fogvatartotti összetételének iskolai végzettségi szintjével, amely sajnálatos módon igen alacsony. A 2015. évi Börtönstatisztikai Szemle szerint a fogvatartottak 0,7 százaléka analfabéta, 12,4 százaléka rendelkezik kevesebb, mint 8 osztállyal, befejezett általános iskolai végzettsége 48,5 százalékának van. 7 százalékuk nem fejezte be a középiskolát, szakiskolai végzettséggel 17,5 százalék, érettségivel 10,6 százalékuk rendelkezik, egyetemet-főiskolát csupán 2,7 százalékuk végzett (Büntetés-végrehajtás Országos Parancsnoksága, 2015).

Az oktatási programok folyamatosan változnak, az elmúlt évek során jelentősen átalakultak, ez a börtönökben folyó tanításra is igaz. A kinti, civil életben elterjedt képzési formák, szakmák a büntetés-végrehajtási intézetekben is megjelentek, az intézetek pedig nyitottá váltak az új lehetőségekre. Ki kell emelni az idegen nyelvü képzéseket és az informatikai kabinetek átadását. Érdekes módon az idegen nyelvü képzés nagyon sok intézetben megbukott, mert a fogvatartottak nagy részének a magyar nyelv írás-olvasásával is komoly nehézségei vannak. A számítástechnikai képzésekkel kapcsolatban a nemzetközi szakirodalomban egyértelmüen az az álláspont, hogy a digitális írástudás hiánya hozzájárul a fogvatartottak egyébként is marginalizált helyzetének további romlásához, ami jelentősen csökkenti szabadulás utáni elhelyezkedésük esélyét. Az infokommunikáció ma már az oktatás integrált részét képezi, így ennek célszerü lenne megjelennie a 
büntetés-végrehajtási oktatás rendszerében is, természetesen a szükséges biztonsági előírások betartása mellett (Braggins és Talbot, 2005; Directorate General..., 2011).

Az oktatási programok mellett folyamatosan módosulnak az oktatásba történő jelentkezés feltételei is. Az utóbbi években pozitív irányú változások mentek végbe ebben a vonatkozásban. Míg néhány évvel ezelőtt csak az jelentkezhetett akár általános iskolai, akár gimnáziumi képzésre, akinek a várható szabadulása a képzések végét követően vált esedékessé, napjainkra ez a rendelkezés már nem érvényes. Ha a fogvatartott minimum fél évet el tud tölteni az oktatásban, részvételének nincs akadálya (Köszegi, 2010). Ez a változtatás nagyon ésszerü, hiszen így a szabadulók esetében nagyobb a motiváló tényező, nagyobb az esélye annak, hogy nem térnek vissza bünöző életmódjukhoz.

Meg kell azonban jegyezni, hogy a fogvatartottak oktatása speciális pedagógiát igényel, nem teszi lehetővé a klasszikus nevelőmunkát. Ruzsonyi (1997) véleménye szerint hiba a „,normál” közegben müködőképes, általános pedagógiai módszereket alkalmazni ezen a területen, mert az csökkenti a hatékonyságot. Ennek ellenére jelenleg a büntetés-végrehajtási intézetekben oktatók nem minden esetben rendelkeznek ilyen irányú speciális felkészültséggel, sőt a felnőtt korú elítélteket oktatók zöme az andragógia sajátosságaival, módszertani kérdéseivel csak a gyakorlatban szembesül (Csukai, 2014).

A börtönoktatásnak az oktatás rendszerébe integrálódva a „második esély” iskolájaként kell müködnie, elősegítve azt, hogy a fogvatartottak le tudják győzni korábbi félelmeiket, negatív tapasztalataikat az iskolai oktatással kapcsolatban, elősegítve ezáltal a társadalomba való sikeres integrálódásukat (Directorate General..., 2011; Diseth és mtsai, 2008).

\section{Egyházak tevékenysége a börtönök falain belül}

Ahogyan az előző szakaszokban olvashattuk, a büntetés-végrehajtási tevékenységben számottevő jelentőséggel bírnak a közremüködő oktatási, társadalmi, egyházi, nonprofit szervezetek. Ebben a fejezetben az egyházi szervezetek kiemelt szerepével foglalkozom.

Hazai és nemzetközi források egyetértenek abban, hogy a börtönben biztosított egyházi programok, lehetőségek hatalmas segítséget jelenthetnek az arra fogékony fogvatartottak számára. Hozzájárulnak ugyanis ahhoz, hogy az elítéltek meg tudjanak birkózni a büntetés-végrehajtási intézet kemény, kíméletlen, néhol embertelen környezetével, ehhez biztosít eröt számukra (Dammer, 2002; Sundt, 1997; Szegál, 2007; Thomas és Zaitzow, 2006).

Az egyház reintegrációban betöltött központi szerepének megértéséhez ki kell emelnünk azt a kontrasztot, ami a vallás és a börtön között felfedezhetö. A börtön mindig a rossz, kellemetlen eseményeket jelenti, így a büncselekményt és a büntetést. A vallás ezzel szemben kellemes, jó dolgokat takar, ehhez kapcsolódóan a szentség és az odaadás fogalmáról beszélhetünk. A fogvatartott egy számüzötthöz hasonlítható, akit a társadalom kivetett magából. A megtérés mozzanata annak az ígéretét hordozza magában, hogy ennek segítségével az elítéltet ezentúl az ,elfogott, letartóztatott, szabadságától megfosztott” jelzők helyett a ,szabad” jelzővel illethetjük (Clear és mtsai, 1992).

Közismert, hogy évszázadokon át az egyházak törődtek a kriminalizált egyénekkel, már a 19. században komoly kísérleteket tettek a börtönbüntetést letöltött személyek rehabilitációjára. Örvendetes az a fejlődés, ami 1989 után a büntetés-végrehajtás és az egyházak közötti együttmüködés terén történt (Teleki, 2010). A magyar büntetés-végrehajtás egyes intézeteibe 1989 öszétől léphetnek be egyházi szolgálat végzése céljából az egyházak és a különféle felekezetek vezetői, valamint a missziós és karitatív szervezetek tagjai, az 13/2000. (VII. 14.) IM rendelet életre hívta a Börtönlelkészi Szolgálatot (Baran, 1997; Hajdú, 2006). A börtönlelkészi szolgálat újbóli létrehozása a hazai büntetés-végrehajtási intézetekben jelentős esemény volt. Mind az egyházak, mind pedig a 
büntetés-végrehajtás nagy figyelmet fordítottak a börtönlelkészi szolgálat müködésének biztosítását szolgáló feltételek megteremtéséhez annak érdekében, hogy a vallásgyakorlás ne csupán alkotmányos alapelv maradjon, hanem napi szinten élhessenek a vallásgyakorlás jogával mindazok, akiknek életében a vallás támogatást, útmutatást jelent (Vári, 2008). A Börtönlelkészi Szolgálat működtetése kapcsán négy missziós szervezet emelhetö ki, amelyek a börtönök és a fogvatartottak segítésére szakosodtak. Ezek a Magyar

Megkülönböztethetjük a börtönlelkészek és a kisegyházak, miszsziós szervezetek büntetés-végrehajtáson belüli tevékenységét. Bizik (2002) szerint a börtönlelkészek ökumenikus jelleg mellett napi 4-8 órában szolid pasztorálást folytatnak, ezzel szemben a kisegyházak a fogvatartottakat a saját gyülekezetükbe szeretnék beszervezni, heti 1-2 órát töltenek hitéleti tevékenységgel a börtönben és rámenós, direkt missziót folytatnak. Véleménye szerint a börtönlelkészek segiteni akarnak, jobban ismerik a börtönviszonyokat, a miszsziók célja inkább a megtérités, és jellemzi óket egyfokú naivitás a börtönviszonyokra vonatkozóan. Mindkét struktúrának vannak pozitivumai és negatívumai, azonban a "missziósok" útja nem a büntetés-végrehajtási lelkészek útja, az a helyes, ha mindkettó szabad teret kap, egymást kiegészítve. Evangéliumi Börtönmisszió, a Magyar Börtönpasztorációs Társaság, a Magyar Máltai Szeretetszolgálat és a Magyar Testvéri Börtöntársaság.

Megkülönböztethetjük a börtönlelkészek és a kisegyházak, missziós szervezetek büntetés-végrehajtáson belüli tevékenységét. Bízik (2002) szerint a börtönlelkészek ökumenikus jelleg mellett napi 4-8 órában szolid pasztorálást folytatnak, ezzel szemben a kisegyházak a fogvatartottakat a saját gyülekezetükbe szeretnék beszervezni, heti 1-2 órát töltenek hitéleti tevékenységgel a börtönben és rámenős, direkt missziót folytatnak. Véleménye szerint a börtönlelkészek segíteni akarnak, jobban ismerik a börtönviszonyokat, a missziók célja inkább a megtérítés, és jellemzi őket egyfokú naivitás a börtönviszonyokra vonatkozóan. Mindkét struktúrának vannak pozitívumai és negatívumai, azonban a „missziósok” útja nem a büntetés-végrehajtási lelkészek útja, az a helyes, ha mindkettő szabad teret kap, egymást kiegészítve.

A börtönlelkész nevelő, tanító szerepe kiegészíti a hagyományos büntetés-végrehajtáson belüli nevelési tevékenységet. Személyiségével kapcsolatban elmondható, hogy az átlagosnál jóval nagyobb pszichológiai állóképességgel kell rendelkeznie. Több türelmet, több áldozatkészséget, empátiát igényel a fogvatartottakkal történő foglalkozás. A pszichológiai állóképesség Vári (2008) által fontosnak tartott három alappillére a börtönlelkész szaktudása, személyiségének adottságai és személyes hite, elhivatottsága, illetve a szolgálata iránt érzett elkötelezettsége. Ezen ismeretek és képességek birtokában a börtönlelkész büntetés-végrehajtáson belüli gyülekezetének tanítója, gondozója, pásztora lehet.

A börtönlelkészi szolgálat föbb feladata a hit- és kegyességi élet, a vallásgyakorlás biztosítása, mise, istentisztelet, biblia- és imaórák tartása; az egyéni és közösségi lelki gondozás; az életismereti, erkölcsi oktatás, nevelés; a vallási tevékenységet végzö szervezetek bv. intézetben történő tevékenységének és a börtönmissziók munkájának koordinálása, valamint a fogvatartottak kérésére egyéb vallásos szertartások végzése (13/2000. 
[VII. 14.] IM rendelet 2. §). A börtönlelkészi szolgálat segítséget nyújt továbbá az elítéltek és szabadultak, valamint családtagjaik gondozása, valláserkölcsi megerösítése terén, a közösségépítésben, az elítélteknek családi kapcsolataik rendezésében, személyes és szociális problémáik megoldásában (Lörincz és Nagy, 1997; Teleki, 2010). A börtönlelkészek lehetőséget kínálnak a fogvatartottak számára, hogy ők maguk ennek segítségével formálhassák magukat. A cél nem az, hogy „oldódjanak a feszültségek”, hogy „,kezelhetőbbé váljanak”, vagy hogy „legyen egy biztonsági szelep”, ezek csupán szerencsés hozadékok, de nem célok (Bízik, 2002).

A fogvatartottak börtönhöz való alkalmazkodása két, jól elkülöníthető módon zajlik, jelenti egyrészt a gondokkal való megküzdést, másrészt a problémás helyzetek elkerülését. Akkor mondhatjuk, hogy egy elítélt meg tud birkózni a szabadságvesztés büntetéssel, ha úgy érzi, képes együtt élni a bezártsággal anélkül, hogy fenyegetettnek, dühösnek, kiszolgáltatottnak vagy nagyon levertnek érezné magát. A problémás helyzetek elkerülése arra vonatkozik, hogy az elítélt le tudja úgy tölteni a büntetését, hogy nem szegi meg a börtönélet szabályait az intézetben töltött idő alatt (Dammer, 2002; Clear és mtsai, 1992).

Szegál (2007) szerint a pasztoráció közvetlen célja az elítéltek hitéletének rendezése, illetve az erkölcsi konfliktusok kezelése, ezáltal a börtön légkörének javítása.

A pasztoráció két módon tud hozzájárulni a börtönélethez való alkalmazkodáshoz Clear és munkatársainak meglátása szerint. Az egyik lehetőség a bebörtönzés által okozott érzelmi megterheléssel való megküzdés segítése, a másik út pedig a börtönkörnyezetben megjelenő nélkülözés megélésének könnyítése. A szabadságvesztés büntetéssel okozott emocionális terheltség csökkentésére vonatkozóan ki kell emelni, hogy a vallás bár nem az egyetlen eszköz, ami segíti a fogvatartottat megérteni, feldolgozni az általa elkövetett hibás lépés, a büncselekmény elkövetésének okait, de az egyetlen eszköz, amely erre vonatkozóan elő tudja írni a megoldási lehetőséget (Clear és mtsai, 1992).

Clear és munkatársai két módot emelnek ki, amely enyhítheti a fogvatartottak bebörtönzés okozta fájdalmát. Az első út a bünösség kezelése. A szabadságtól való megfosztást leszámítva a bebörtönzés legfontosabb üzenete a bünösség tényének hangsúlyozása. A fogvatartottak a valláshoz fordulhatnak megkönnyebbülés iránti vágyból, mintegy vezekelve, amiért elkövették az adott büncselekményt. Sok elítélt nem bocsát meg magának az általa elkövetett büncselekmény miatt. A második út az új élet ígérete. Az elítéltek hangsúlyozzák, hogy a vallás megváltoztatta őket, ennek hatására teljesen új életet kezdtek. Az igazán mélyen vallásos fogvatartottak nagyon komolyan veszik a vallás elöírásait, az egyházi doktrínák bizonyossága, kiszámíthatósága igazán vonzó számukra a saját bizonytalan életük megváltoztatása kapcsán, új életüknek teljesen alárendelik a régi életüket, erőt merítve ebből a változásból. Megérzik Isten életükben betöltött aktív szerepét, ez segít nekik elviselni a bebörtönzés okozta fájdalmakat (Clear és mtsai, 1992).

A börtönpasztorációnak rengeteg előnye van a fogvatartottak számára. Egyrészről a lelkészi meghallgatás egy elöítéletektől mentes kapcsolat felajánlását jelenti, a lelkész ugyanis bátorítja a fogvatartottakat, hogy nézzenek szembe saját élettörténetükkel, nem szidja öket az elkövetett hibákért, nem ad fegyelmit, feddést. Másodsorban a pszichológusi (,elmebeteg”, „örült"), illetve a nevelői meghallgatással („,besúgó”, „árulkodó”) ellentétben nem vonja maga után a társak rosszallását, szinte kivétel nélkül minden fogvatartottban van ugyanis egy alapvető tisztelet a vallás iránt (Czenczer, 2008).

A börtönlelkészi látogatások, foglalkozások hatására a fogvatartottak pszichés klímáján, fegyelmi helyzetén, önbecsülésén jól érzékelhetők a pozitív élmények, amelyek hozzájárulnak ahhoz, hogy minél kevesebb lelki sérüléssel tudjanak visszaintegrálódni a társadalomba (Baran, 1997). A fó feladatok - Estók (2002) megfogalmazása szerint „az elítéltek morális tartásának újraépítése, egy valóban igazi emberkép kialakítása, formálása, az örök érvényü törvények szerint, azaz az erkölcsi, etikai morál pozitív irányú befolyásolása". A lelkészi jelenlét a fogvatartott számára a belső tartás erősítését jelenti. 
A problémák megbeszélése, a szorongást keltő forrásokkal való együttes szembenézés segíthet a frusztráció csökkentésében. A börtönlelkésznek fontos kiegyensúlyozó szerepe van az elítéltek önértékelésének erösítésében, ennek eszköze a másikra való tartós és előítélet-mentes odafigyelés. Gyakori probléma a börtönben az agresszió, az agresszív késztetések kioltása, jelentős enyhítése lehetséges verbális, igei, bibliai eszközökkel, énekléssel, a közös lelki élmények terápiai hatásával. Hasznos továbbá a konstruktív jellegü beszélgetés a konfliktusokról, amelyek a fogvatartottat agresszív magatartáshoz vezették. Ennek során a fogvatartott megtapasztalja a börtönlelkész és az istentiszteleti közösség együttműködő-segítő hozzáállását a problémájához, segítséget nyújthat annak feldolgozásában. Fontos börtönlelkészi feladat továbbá az önértékre nevelés, mivel általánosan elfogadott nézet a szakirodalomban, hogy csak erős személyiség tud tartósan megküzdeni a zárt intézeti viszonyokkal, a bünözés ismétlődésének kényszerével (Békeffy, 2005).

Nem kérdőjelezhető meg a lelkipásztori hatás elítélt személyiségét, értékrendjét befolyásoló szerepe, azonban Szegál (2007) felhívja arra a figyelmet, hogy „nem rendelkezünk olyan megbízható, objektív adatokkal, amelyek egyértelmüen jeleznék a pasztoráció reszocializációs súlyát". A börtönlelkészi szolgálat büntetés-végrehajtási intézetekben való létjogosultságát a legmagasabb közigazgatási szinteken is elismerik, vagyis tény, hogy a lelkészi szolgálat - a civil szervezetek jelenlétének pozitív hatásához hasonlóan - integrálódott a büntetés-végrehajtási szervezetbe (Vári, 2008).

\section{Civil szervezetek szerepe}

A nonprofit szervezetek összetett tevékenységrendszerükön keresztül hozzájárulnak a fogvatartottak társadalomba való visszaillesztéséhez. Fontos a nonprofit szervezetekkel való viszony ápolása többek között a fogvatartottak világgal való kapcsolattartása, a családdal való viszonyának támogatása, a munkához való hozzáállásának alakítása miatt is. A büntetés-végrehajtás rendszerének igenis szüksége van ezekre a szervezetekre, mert ezen impulzusok biztosítása által hatékonyabbá válik a rendszer müködése, a fogvatartottak társadalomba való reintegrálásának elősegítése.

A nemzetközi szakirodalom a civil szervezetek büntetés-végrehajtási rendszerben való müködéséhez kapcsolódóan négy fő irányt különít el. Az első két csoportba tartozó civil szervezetek konkrétan az egyes fogvatartottak segítése, támogatása által tevékenykednek, míg a harmadik, negyedik célt képviselő NGO-k jellemzően inkább hatóságoknál, kormányoknál, más döntéshozóknál kívánnak pozitív változást elérni az elítéltek élethelyzetére vonatkozóan. Ezek felvázolása során minden nonprofit szervezeti preferencia esetében bemutatok egy-két nemzetközi, illetve hazai civil szervezetet, amely az adott területen tevékenykedve képviseli a fogvatartottak érdekeit.

Először meg kell említenünk azokat a civil szervezeteket, amelyek témánk szempontjából a leginkább meghatározó jelentőségűek, és a büntetés-végrehajtási intézetekben müködve járulnak hozzá a fogvatartottak szabadulás utáni reintegrációjához speciális programok, így oktatás, képzés, készségfejlesztés, munkaerőpiacra visszavezetés segítségével (United Nations..., 2000). A büntetés-végrehajtás nevelési tevékenységének bővítésére, színesítésére több értékes hazai példa szolgálhat mintaként. Ezek eredményesen alkalmazhatók az intézetek személyi állományának létszáma, leterheltsége ismeretében, illetve az intézetek müködését meghatározó költségvetési és jogszabályi körülmények között (Szitka, 2008).

A hazánkban müködő, börtönökkel szoros kapcsolatot ápoló szervezetek egy részének célja az oktatás, képzés elősegítése. Számos általános iskolával, valamint gimnáziummal együttmüködve a börtönviseltek képzését célozza meg szociális munkás és szociálpedagógus hallgatók segítségével, szupervízióval és esetmegbeszéléssel például a Belvárosi 
Tanoda Váltó Programja. Célja a negatív énkép megváltoztatása és a személyiségfejlesztés, ami természetesen csak a büncselekmény (pszichés, mentális, szociális, szociokulturális, értékrendi stb.) okainak feltárása és a büntudat feldolgozása után, vagy azzal párhuzamosan következhet be (Teleki, 2010).

A szabadulás utáni sikeres beilleszkedéshez kulcsfontosságú, hogy a bünelkövetőt vagy szabadultat egy elfogadó csoport vegye körül, amely támogatja őt. A szabadulás krízishelyzetének csökkentését, a biztonságos felnőtt kapcsolat kiépítését már a büntetés-végrehajtási intézeten belül kell elkezdeni. A bizalom elnyerése és megerősödése, a folyamatos érzelmi biztonság megteremtése, az elfogadó közösség segítségnyújtása az utógondozás és a visszaesés-megelőzés alappillérei (Mészáros, 2002).

Számos hazai civil szervezet célja igencsak összetett, túlmutat a fogvatartottak oktatásán, képzésén, komplexebb küldetéssel rendelkezik. Ide sorolhatjuk a fogvatartottak és a szabadultak társadalmi és munkaerőpiaci beilleszkedésének támogatását, a társadalmilag leszakadt rétegek felzárkóztatását és az esélyegyenlőség megteremtését célul tüző civil szervezeteket. Ezek tevékenyen hozzájárulnak a társadalmi integrációs folyamatok kialakításához, a büntetés-végrehajtásban különös tekintettel a nevelés, oktatás, képességfejlesztés, kulturális tevékenység és hátrányos helyzetű csoportok társadalmi esélyegyenlőségének elősegítése által. Ilyen összetett célt tüzött ki például a Váltó-sáv Alapítvány, amely egy országosan müködő civil szervezet, célja a fogvatartottak és a szabadultak (elsősorban fiatalok, 16-35 évesek) társadalmi és munkaerőpiaci beilleszkedésének támogatása, azaz a büntető eljárásban terheltnek minősülők megkeresése, gondozása, képzése, mentálhigiénés ellátása és reszocializációja (Csáki és Mészáros, 2003).

Meghatározó jelentőségű cél az oktatás, képzés, reintegráció mellett annak megelözése, hogy a büntetés-végrehajtás következtében szétessenek a családi kapcsolatok, szülö-gyerek viszonyok meggyengüljenek. A család kiemelten resztoratív közeg, amely alapvető szerepet játszik a megbélyegzés csökkentésében, segít megakadályozni a visszaesést, könnyebbé teszi a volt fogvatartott szabadulás utáni beilleszkedését a társadalomba (United Nations..., 2000). Hazánkban számos civil szervezet, így például a Tévelygőkért DRK Alapítvány célja az esélyegyenlőtlenség megszüntetése a marginalizált csoportokkal való közös munka, valamint társadalmi érzékenyítés révén. Az alapítvány tevékenységének fő területe a büntetés-végrehajtási rendszer által hátrányosan érintettek támogatása, amely össztársadalmi problémákat céloz meg, így érinti a gyermekjog, a mélyszegénység, valamint a roma-magyar együttélés egyes kérdéseit. Az Alapítvány munkájának fókuszában az elítéltek, a szabadultak, illetve az ő családjaik állnak. A család kiemelten fontos védelmező közeg, amely alapvető szerepet játszik a karcerizáló hatások csökkentésében. A gyerekeknek szüksége és joga van a szüleivel való kapcsolattartásra, amely az eljárástól függően traumatizálhatja vagy javíthatja a szülökkel való kapcsolatot. ${ }^{1}$

A szabadulásra felkészítés technikusai hiába tudják a visszailleszkedés hivatalos menetrendjét, gyakorlati teendőit, ha a szabaduló nem képes az új életében elképzelni magát. Az új képzettség új lehetőségeket, új státust, új életformát is jelent, ennek a felkészítő munkának a során szükség szerint segíteni kell őket, így megteremteni és megörizni testi és mentális egészségüket, feldolgozni a helyzetüket, szabadulás utáni életük minőségén javítani, tanulásra, alkotásra inspirálva őket elboldogulni a munka világában. Ehhez nyújt segítséget a B-Terv program a szabadultak társadalmi integrációjáért. Ennek célja személyre szabott megoldások keresése olyan büntetés-végrehajtásból szabadult személyek számára, akiket nem vár család és nincsen lakhatási és munkalehetőségük. Számukra a program keretében minden szükséges segítséget megadnak ahhoz, hogy a saját lábukra állhassanak, ide sorolva a tanácsadást, ügyintézést, munkakeresést és a lakhatás támogatását. ${ }^{2}$ Enélkül ugyanis sokkal magasabb a visszaesés valószínüsége a frissen szabadultak esetében. 
Szintén a szülő-gyermek kapcsolat erősítése a célja az Add a kezed Közhasznú Egyesületnek. ${ }^{3}$ „Ha valakit börtönbe zárnak, az nem csak az egyén problémája, ugyanúgy érinti a családját, feleségét, férjét, és kiemelten a gyerekeit" - vallja Kóka Ágnes, az egyesület vezetője, hangsúlyozva, hogy a bebörtönzés hátrányos hatásrendszere hazánkban jelenleg közel 40000 gyermeket érint. Az egyesület a családi kapcsolatok újjáépítését és segítését célul tüző programban 15

\section{A hazai büntetés-végrehajtási} gyakorlatban csíráiban több éve megfigyelhetó, de lehetôségeinek megfelelóen nem kezelt kezelési módszer a drámapedagógia. A közösség erejének segitségül hivása az egyén alakitásában a gyakran konfliktust hordozó emberi élethelyzetek eljátszásá-

\section{val, feldolgozásával régóta} ismert a magyar neveléstudományban, terápiás, neveló és fejlesztô hatása bizonyitott. A Feldmár Intézet keretén belül múködik a Mesekör program, amelynek szakmai tapasztalatait átvéve a Tévelygókért Alapitvány 2014 júniusa óta dolgozik a Balassagyarmati Fegyház és Börtönben a fogvatartottakkal. A program keretében a fogvatartott apák saját életük élményeiból dolgoznak fel az archaikus mesék hagyományainak szellemében sztorikat, melyeket saját maguk dramatizálnak, rendeznek, majd elóadják a gyerekeiknek. olyan családnak szervezett foglalkozásokat, ahol az édesanya a börtönbüntetését töltötte a Heves megyei Büntetés-végrehajtási Intézetben. A szakmai tevékenység részben a végrehajtási intézetekben élő nőkre, részben ezen anyák családtagjaira, közvetlen környezetére irányul. A projekt legfontosabb programelemei a meseterápia és a családfejlesztő tréning voltak, emellett életvezetési tanácsokat is nyújtottak a fogvatartottak számára. A program részeként az egyesület egy családi napot szervezett, amelynek keretében 15 fogvatartott édesanya találkozhatott gyermekeivel Felsőtárkányban egy közösségi élményekben gazdag családi nap keretében. A program egyértelműen csökkentette a családtagok, gyermekek szorongását, segített objektív képet kialakítani a családtagokban a fogva tartás körülményeiről, emellett eredményeként körvonalazódni látszik a szabadulás utáni családi kapcsolatok helyreállításának lehetősége is. ${ }^{4}$

A hazai büntetés-végrehajtási gyakorlatban csíráiban több éve megfigyelhető, de lehetőségeinek megfelelően nem kezelt kezelési módszer a drámapedagógia. A közösség erejének segítségül hívása az egyén alakításában a gyakran konfliktust hordozó emberi élethelyzetek eljátszásával, feldolgozásával régóta ismert a magyar neveléstudományban, terápiás, nevelő és fejlesztő hatása bizonyított. A Feldmár Intézet keretén belül müködik a Mesekör program, amelynek szakmai tapasztalatait átvéve a Tévelygőkért Alapítvány 2014 júniusa óta dolgozik a Balassagyarmati Fegyház és Börtönben a fogvatartottakkal. A program keretében a fogvatartott apák saját életük élményeiböl dolgoznak fel az archaikus mesék hagyományainak szellemében sztorikat, melyeket saját maguk dramatizálnak, rendeznek, majd előadják a gyerekeiknek. ${ }^{5}$

Az NGO-k müködésének harmadik fö iránya a börtönben fogva tartott személyek emberi jogainak védelme, azok megsértésének megakadályozása. Néhány civil szervezet a börtönön belüli kínzás, vagy más kegyetlen, embertelen, lealacsonyító bánásmód ellen kíván fellépni. Az NGO-k egy része perek indításával kívánja kitűzött célját elérni hazai, 
illetve nemzetközi szinten egyaránt (United Nations..., 2000). Ilyen szervezet a bécsi székhelyü Helsinki Bizottság (International Helsinki Federation for Human Rights), amely számos európai országban müködik nonprofit szervezetként, elsődleges céljának tartva az emberi jogok védelmének biztosítását. Hazánkban is müködik szervezete, a Magyar Helsinki Bizottság, amelyet 1989-ben alapítottak. ${ }^{6}$ Egyesületi formában, civil jogvédő szervezetként tevékenykedik, az emberi méltóságot védelmezi a jog és nyilvánosság eszközével. A szervezet segítséget biztosít a börtönben elszenvedett jogtalanságok, hatósági bántalmazás, kényszervallatás és jogellenes fogvatartás áldozatainak. ${ }^{7}$

Szintén az emberi jogok elismeréséért fellépő nemzetközi szervezet az Amnesty International (AI). Ez egy független demokratikus szervezet, amely kormányoktól, politikai pártoktól, egyházaktól függetlenül müködik. Ajánlásokat fogalmaz meg az emberi jogi sérelmek megszüntetésére, és azokat kampányok segítségével igyekszik érvényesíteni kormányoknál. Az Amnesty International Magyarország (AI Magyarország) egyesületi formában müködik, munkája szorosan kapcsolódik a nemzetközi kampányokhoz. A magyar szervezet feladatának tekinti azt is, hogy egyes magyarországi emberi jogi problémákkal kapcsolatban szót emeljen és fellépjen, ezáltal hozzájárulva a magyarországi emberi jogi helyzet javításához. ${ }^{8}$

A büntetés-végrehajtás rendszerében dolgozó civil szervezetek negyedik csoportja a korrupció megelőzését tüzte ki célul. A börtönök hermetikus struktúrájuk, bünözőkkel folytatott napi munkájuk, alulfizetett személyzetük miatt erösen veszélyeztetettek korrupciós szempontból. A korrupció ellen küzdő NGO-k megpróbálják a társadalom figyelmét erre a kérdésre irányítani, ilyen módon fellépni ezen igen súlyos probléma ellen (United Nations..., 2000, 11. o.). Az egyik legfontosabb nemzetközi NGO, amely ezzel a témával foglalkozik, a Transparency International, számos államban működtet irodát. A Magyarországon folytatott korrupció elleni küzdelem fontos állomása volt 1996-ban a Transparency International magyarországi tagozatának megalapítása. Az egyesületi, majd alapítványi formában müködő civil szervezet célja az volt, hogy a korrupció természetét, okait, különböző megnyilvánulási formáit kutató tényfeltáró munkával javaslatokat fogalmazzon meg a korrupció számára kedvezőtlen közgazdasági és jogi környezet kialakítására. Küldetése független, szakmai szervezetként elösegíteni a korrupció megfékezését, ösztönözni az átláthatóságot és számonkérhetőséget a közhatalmi döntéshozatalban és a közpénzeket érintő folyamatokban, valamint javítani a közérdekü információk elérhetőségét. ${ }^{9}$

Hazánkban a fentebb bemutatott négy NGO-típus mellett jelen van egy ötödik is, amely civil kapcsolatteremtési lehetőséget biztosít a büntetés-végrehajtás rendszere iránt érdeklődők számára. Ez a Magyar Börtönügyi Társaság, amely civil szervezetként jött létre, alapvető célja az volt, hogy civil kapcsolatteremtési lehetőséget biztosítson a büntetés-végrehajtás rendszere iránt érdeklődők számára. A Társaság célja a börtönügy korszerüsítésére irányuló törekvések támogatása, a tudományos kutatások szervezése és lebonyolítása, a börtönüggyel kapcsolatos ismeretek, kutatási eredmények terjesztése, a hiteles tájékoztatás elösegítése.

A büntetés-végrehajtás és a civilek mind az öt kitűzött cél esetében a segítő szándék jegyében, de külön-külön tevékenykednek, ami a hatásfokot nagymértékben csökkenti. Döntő jelentőségű ezért, hogy a szakemberek, munkatársak kölcsönösen megismerjék egymást, aminek következtében a folyamatos jelenlét, valamint a kommunikáció mindkét félnél attitüdváltozáshoz vezethet (Csáki és Mészáros, 2005). A civil szervezetek által szervezett programok olyan célorientált beavatkozások, amelyek minden esetben a fogvatartottak fizikai, érzelmi, szociális és kognitív funkcióinak javítását tüzik ki célul. 


\section{Záró gondolatok}

Ha a börtöntanárok, az egyházak tevékenységét vagy a civil szervezetek áldozatos munkáját vizsgáljuk, elmondható, hogy a változás a rendszeres foglalkozási alkalmakon, illetve az azok közötti időszakban az önképzés, az alkotó munka által és során a segítő odafordulás hatására spontán módon zajlik.

Az egyházak képviselői, civil szervezetek munkatársai tevékenységük gyakorlása során lelki gondozást látnak el, emberi odafigyelést mutatnak az elítéltek felé, hogy szükség esetén legyen kivel megbeszélni azokat a problémákat, amikkel egyedül nem boldogulnak. A börtönt és annak számtalan velejáróját ugyanis nagyon nehéz feldolgozni. A civil szervezetek azért is vesznek részt ebben a folyamatban, mert küldetéstudattal rendelkeznek, szilárd belső meggyőződésük, hogy minden ember azonos értékü tagja a társadalomnak, akinek joga van a segítséghez (Végh, 2008). „A civileknek azért kell bejárniuk a börtönökbe, hogy kéznél legyenek, ha szükség van rájuk, és azért kell kéznél lenniük, hogy rá lehessen döbbenni, hogy rájuk van szükség. Hogy puszta jelenlétükkel is bizonyíthassák: van palló átkelni a fölött az irdatlan alatt mélység fölött, amit egy érzékenyebb rab megnyílni lát maga előtt!" (Végh, 2008)

Tanulmányomban megpróbáltam rámutatni arra a közeledési, együttmüködési, közös gondolkodási, tenni akarási folyamatra, amely jelenleg is zajlik a hazai büntetés-végrehajtás rendszerében a különböző szereplők között. Jól látható, hogy az állami intézményrendszer és az egyházak képviselői, valamint a civil szervezetek nyitottak egymásra, kölcsönösen tudnak tanulni egymástól, és így talán egyre több büntetés-végrehajtási intézetben lesz a jövőben is olyan program, ami értékes emberként, partnerként tud közelíteni az elítéltekre, elősegítve ezzel szabadulásuk utáni sikeres reintegrációjukat, társadalomba való visszailleszkedésüket.

\section{Irodalomjegyzék}

13/2000. (VII. 14.) IM rendelet a Börtönlelkészi Szolgálat létrehozásáról

16/2014. (XII. 19.) IM rendelet a szabadságvesztés, az elzárás, az előzetes letartóztatás és a rendbírság helyébe lépő elzárás végrehajtásának részletes szabályairól

1995. évi CVII. törvény a büntetés-végrehajtási szervezetről

2013. évi CCXL. törvény a büntetések, az intézkedések, egyes kényszerintézkedések és a szabálysértési elzárás végrehajtásáról

Baran Katalin (1997): Misszió. Karitatív tevékenység a Budapesti Fegyház és Börtönben. Börtönügyi Szemle, 16. 2. sz. 79-80.

Békeffy Lajos (2005): A problémakezelö-személyiségfejlesztő börtönpasztorizáció néhány elvi és gyakorlati kérdése. II. rész. Börtönügyi Szemle, 24. 1. sz. 83-92.

Bízik László (2002): A börtön a templomunk. Lelkipásztor, 77. 3. sz. 97-99.

Braggins, J. és Talbot, J.(2005): Wings of Learning; the role of the prison officer in supporting prisoner education. Centre for Crime and Justice Studies. http://www.esmeefairbairn.org.uk/pdf/wings of learning.pdf

Brosens, D., Donder, L., Dury, S. és Verté, D. (2015): Barriers to Participation in Vocational Orientation Programmes Among Prisoners. Journal of Prison Education and Reentry, 2. 2. sz. 9-22. DOI: 10.15845/ jper.v2i2.817

Burik Mónika (2011): A magyar és külföldi büntetésvégrehajtási intézetek pénzügyi és gazdasági tevékenységének összehasonlitása. Doktori értekezés. Nyugat-magyarországi Egyetem Széchenyi István Gazdálkodás- és Szervezéstudományok Doktori Iskola, Sopron. http://www.nyme.hu/fileadmin/dokumentumok/ktk/Kepzes doktori/2011/2011 BurikMonika_d.pdf

Callan, V. és Gardner, J. (2005): Vocational education and training provision and recidivism in Queensland correctional institutions. National Center for Vocational Education Research, Adelaide.

Clear, T., Dammer, H., Hardyman, P., Kelly, L., Shapiro, C. és Stout, B. (1992): Does Involvement in Religion Help Prisoners Adjust to Prison? (FOCUS) National Council on Crime and Delinquency. Nov. 1. http://www.issuelab.org/resource/does_involvement in religion help prisoners adjust to prison focus 
Czenczer Orsolya (2008): Fiatalkorúak reszocializációs nevelése a szabadságvesztés büntetés alatt. Doktori értekezés. Kézirat. Károli Gáspár Református Egyetem Állam- és Jogtudományi Doktori Iskola, Budapest.

Csáki Anikó, Kovács Klaudia, Mészáros Mercedes és Sponga István (2006): Fogvatartásból szabadult fiatal felnöttek társadalmi (re)integrációjának lehetöségei. Kutatási összefoglaló. Ifjúsági, Családügyi, Szociális és Esélyegyenlőségi Minisztérium, Budapest.

Csáki Anikó és Mészáros Mercédesz (2003): Pedagógiai munka a szabadságvesztés alatt és után. Educatio, 12. 2. sz. $265-278$.

Csáki Anikó és Mészáros Mercédesz (2005): Szociális munka a büntetés-végrehajtásban és az utógondozásban. Esély, 15. 2. sz. 95-114.

Csukai Magdolna (2014): Oktatás a büntetés-végrehajtási intézetekben. Hadtudományi Szemle, 7. 4. sz. 188-194.

Dammer, H. R. (2002): Religion in corrections. In: The Encyclopedia of Crime and Punishment. Sage Publications. Vol. 3. 1375. http://www.scranton.edu/ faculty/dammerh2/ency-religion.shtml. DOI: $10.4135 / 9781412950664$

Directorate General for Education and Culture, European Commission (2011): Prison education and training in Europe - a review and commentary of existing literature, analysis and evaluation.

Diseth, Å., Eikeland, O.-J., Manger, T. és Hetland, H. (2008): Education of prison inmates: course experience, motivation, and learning strategies as indicators of evaluation. Educational Research and Evaluation, 14. 201-214. DOI: $10.1080 / 13803610801956614$

Eggleston, C. R. (1991): Correctional education professional development. Journal of Correctional Education, 42. 1. sz. 16-22.

Estók József (2002): A börtönpasztoráció és a börtönlelkészi szolgálat helyzete. Sárospataki füzetek, 6.1. SZ. 5-9.

Forgács Judit (2012): Merre tart a nevelés? A nevelői profil vizsgálata. Börtönügyi Szemle, 31. 1. sz. 63-72.

Garami Lajos (1997): Száz szervezet. Másik nézőpont az együttmüködésröl. Börtönügyi Szemle, 16. 2. Sz. 74-78.

Gemignani, R. (1994): Juvenile Correctional Education: A Time for Change. Office on Juvenile Justice and Deliquency Preventation. Juvenile Justice Bulletin, October, 2-4. DOI: 10.1037/e381002004-001

Gerber, J. és Fritsch, E. J. (1993): Adult Academic and Vocational Correctional Education Programs: A Review of Recent Research. Journal of Offender Rehabilitation, 22. 1-2. sz. 119-142. DOI: 10.1300/ j076v22n01 08
Hajdú Miklós (2006): A börtönpasztorizáció lehetőségei a büntetés-végrehajtásban. Börtönügyi Szemle, 25. 1. sz. 33-36.

Hurry, J., Brazier, L., Snapes, K. és Wilson, A. (2005): Improving the literacy and numeracy of disaffected young people in custody and in the community. http://www.nrdc.org.uk/publications details.asp? ID $=28 \#$

Juhász Zsuzsanna (2002): A hazai büntetés-végrehajtási jog és az Európai Börtönszabályok ajánlásai. Szegedi Tudományegyetem Állam- és Jogtudományi Kar, Szeged.

Köszegi Szilvia (2010): A fogvatartottak oktatása és képzése. Börtönügyi Szemle, 29. 3. sz. 55-62.

Lőrincz József és Nagy Ferenc (1997): Börtönügy Magyarországon. Büntetés-végrehajtás Országos Parancsnoksága, Budapest.

Mészáros Mercédesz (2002): Letartóztatásban lévő fiatal felnőttek reszocializációja. Börtönügyi Szemle, 21. 4. sz. 41-54.

Módos Tamás (1998): Büntetés-végrehajtási nevelés. Rejtjel Kiadó, Budapest.

Novák Zoltán (2004): A fogvatartottak oktatása, szakképzése a büntetés-végrehajtási intézetekben. Börtönügyi Szemle, 23. 4. sz. 47-58.

O'Keeffe, C., Senior, P. és Monti-Holland, V. (2007): Barriers to employment, training and education in prison and beyond: A peer-led solution. In: Sheehan, R., McIvor, G. és Trotter, C. (szerk.): What works with women offenders. Willian Publishing, Portland. 240-261. DOI: 10.4324/9781843924944

Paul, M. (1991): When Words are Bars. In: Kitchener. Core Literacy, Ohio.

Ripley, P. (1993): Prison Education Role in Challenging Offending Behaviour. Mendpg Papers 047. https://archive.org/stream/ERIC ED377405/ ERIC_ED377405_djvu.txt

Ruzsonyi Péter (1997): Új megközelítés: a konstruktív életvezetés megalapozásának korrekciós-pedagógiai rendszere. Börtönügyi Szemle, 16. 4. sz. 82-95.

Ruzsonyi Péter (1999): Javíthatatlanok? A büntetésvégrehajtási korrekciós nevelés fejlödési trendje. Börtönügyi Szemle, 18. 4. sz. 24-45.

Ruzsonyi Péter (2006a): A kriminálpedagógia lehetősége a börtönadaptáció és a társadalmi integrálódás érdekében. Börtönügyi Szemle, 25. 2. sz. 21-33.

Stephens, R. (1992): To What Extent and Why do Inmates Attend School in Prison. Journal of Correctional Education, 43. 1. sz. 52-56.

Sundt, J. L. (1997): Bringing Light to Dark Places: An occupational study of prison chaplains. Doctoral Dissertation. University of Cincinnati. http://cech. uc.edu/content/dam/cech/programs/criminaljustice/ docs/phd_dissertations/1997/Sundt.pdf 
Szegál Boris (2007): A szocializáció és reszocializáció a börtönben. Börtönügyi Szemle, 26. 3. sz. 25-38.

Szitka Szabolcs (2008): Új lehetőségek felkutatása a fiatalkorúak büntetés-végrehajtásában, reszocializációjuk elősegítése érdekében. Börtönügyi Szemle, 27. 3. sz. 13-20.

Teleki Béla (2010): A szabadultak szociálpedagógiai ellátása. Börtönügyi Szemle, 29. 3. sz. 31-36.

Thomas, J. és Zaitzow, B. H. (2006): Conning or Conversion? The Role of Religion in Prison Coping. The Prison Journal, 86. 2. sz. 242-259. DOI: $10.1177 / 0032885506287952$
Vacca, J. S. (2004): Educated prisoners are less likely to return to prison. The Journal of Correctional Education, 55. 4. sz. 297-306.

Vári Krisztina (2008): A börtönlelkészség hét éve Magyarországon. Börtönügyi Szemle, 27. 1. sz. 48-62.

Végh József (2008): Pallók a mélység fölött. A civilek szerepe a büntetés-végrehajtásban. Börtönügyi Szemle, 27. 1. sz. 83-92.

Wright, R. (2004): Care as the „Heart” of Prison Teaching. Journal of Correctional Education, 55. 3. sz. 191-209.

\section{Jegyzetek}

${ }^{1}$ http://www.tevelygokertalapitvany.info/\#!rolunk/ $\operatorname{csg} z$

${ }^{2}$ http://www.tevelygokertalapitvany.info/\#!b-terv/ c24jf

${ }^{3}$ http://www.addakezedkhe.com/egyeb/bemutatkozunk

4 http://www.addakezedkhe.com/egyeb/ ncta-2013-3822-g-csaladi-kapcsolatok-ujjaepitesenek-segitese
${ }^{5}$ http://www.tevelygokertalapitvany.info/\#! mesekor-a-bortonben/c1mj4

${ }^{6}$ http://www.helsinki.hu/kik-vagyunk/

${ }^{7}$ http://www.helsinki.hu/rendeszet-es-bunteto-igazsagszolgaltatas/

${ }^{8} \mathrm{http}: / /$ www.amnesty.hu/amnesty-international

${ }^{9} \mathrm{http}: / /$ transparency.hu/TORTENET 